University of Wollongong

Research Online

Faculty of Engineering - Papers (Archive)

Faculty of Engineering and Information

Sciences

March 2007

\title{
Analytical solutions and design curves for vacuum-assisted consolidation with both vertical and horizontal drainage
}

Cholachat Rujikiatkamjorn

University of Wollongong, cholacha@uow.edu.au

Buddhima Indraratna

University of Wollongong, indra@uow.edu.au

Follow this and additional works at: https://ro.uow.edu.au/engpapers

Part of the Engineering Commons

https://ro.uow.edu.au/engpapers/358

\section{Recommended Citation}

Rujikiatkamjorn, Cholachat and Indraratna, Buddhima: Analytical solutions and design curves for vacuumassisted consolidation with both vertical and horizontal drainage 2007.

https://ro.uow.edu.au/engpapers/358

Research Online is the open access institutional repository for the University of Wollongong. For further information contact the UOW Library: research-pubs@uow.edu.au 


\title{
ANALYTICAL SOLUTIONS AND DESIGN CURVES FOR VACUUM- ASSISTED CONSOLIDATION WITH BOTH VERTICAL AND \\ HORIZONTAL DRAINAGE
}

\author{
Cholachat Rujikiatkamjorn \\ BEng (Hons), MEng (AIT), PhD
}

Research Associate, Civil Engineering, Faculty of Engineering, University of

Wollongong, Wollongong, NSW 2522, Australia

\begin{abstract}
Buddhima Indraratna $^{\dagger}$
$\mathrm{PhD}$, DIC, MSc (Lond.), FIEAust.,

Professor of Civil Engineering, Faculty of Engineering, University of Wollongong, Wollongong, NSW 2522, Australia

Tel: +61-2-4221-3046; Fax: +61-2-4221-3238

e-mail: indra@uow.edu.au

${ }^{\dagger}$ Corresponding author: Prof. Buddhima Indraratna, e-mail: indra@uow.edu.au

School of Civil Engineering, Faculty of Engineering, University of Wollongong, Wollongong City, NSW 2522, Australia,
\end{abstract}

Submitted to: Canadian Geotechinical Journal

MS05-135 


\title{
ANALYTICAL SOLUTIONS AND DESIGN CURVES FOR VACUUM- ASSISTED CONSOLIDATION WITH BOTH VERTICAL AND HORIZONTAL DRAINAGE
}

\author{
Cholachat Rujikiatkamjorn and Buddhima Indraratna
}

\begin{abstract}
A system of vertical drains combined with vacuum preloading is an effective method for promoting radial flow to accelerate soil consolidation. This study presents the analytical modeling of a consolidation of vertical drains incorporating vacuum preloading considering both vertical and horizontal drainage. The effects of a number of dimensionless parameters involving the drain length, soil permeability and vacuum pressure are examined through average excess pore pressure, degree of consolidation, associated settlement and time factor analyses. An analysis of selected case histories compliments the use of the proposed solutions. Design charts are also presented for practical use.
\end{abstract}

Key words: Analytical solution, Consolidation, Design charts, Vertical drains. 


\section{Introduction}

Vacuum preloading method was first introduced by Kjellman (1952) to improve the strength of soft soil. An increase in the effective stress in a soil mass for this method is attributed to applying a vacuum pressure in lieu of a conventional surcharge (Qian et al. 1992). This system has been used to achieve a rapid consolidation and reduce the height of surchage fill by vacuum pressure acting as an additional surcharge load. The advantages of vacuum preloading in comparison with conventional preloading can be summarised as follows:

(a) The effective stress related to suction pressure increases equiaxially, and the corresponding lateral movement is compressive. Consequently, the risk of shear failure can be minimised even at a higher rate of embankment construction (Qian et al. 1992).

(b) Depending on the vacuum efficiency (e.g., extent of air leaks in the field), the height of surcharge fill can be decreased to achieve the same amount of settlement.

(c) At any given time, the maximum excess pore pressure prevailing under a vacuum preloading system is less than a conventional surcharge.

(d) With a vacuum pressure applied through prefabricated vertical drains, the risk of unsaturation at the soil-drain interface due to mandrel withdrawal may be reduced (Indraratna et al. 2004).

Prefabricated vertical drains (PVDs) can affect the distribution of vacuum pressure to deep subsoil layers and thereby increase the consolidation rate (Holtan 1965, Chu et al. 2000). The effectiveness of vacuum consolidation via PVDs for ground improvement has been verified through various field trials (Choa 1989; 
Shinsha et al. 1991; Indraratna et al. 2004). In the case of hydraulic fill used in land reclamation projects where the height of surcharge is restricted due to the low shear strength of soft soil, vacuum-assisted consolidation is an ideal method for ground improvement (Yan and Chu, 2003; Song and Kim, 2004). However, the effectiveness of this system depends on: (a) the integrity (airtightness) of the membrane, (b) the effectiveness of the seal between the edges of the membrane and the ground surface, and (c) soil conditions and the location of ground water level (Cognon et al. 1994).

The theory of radial drainage and consolidation was initially presented by Carrillo (1942) and Barron (1948). Subsequently, Yoshikini and Nakanodo (1974) proposed a rigorous solution that included well resistance. Hansbo (1981) and Onoue (1988) extended these solutions to take the smear effect into account. In terms of vacuum preloading, a rigorous solution for vertical consolidation was proposed by Mohamedelhassan and Shang (2002), whereas a solution for radial consolidation was introduced by Indraratna et al. (2005). However, to the authors' knowledge, no comprehensive solution to vacuum-assisted consolidation with both vertical and horizontal drainage including the smear effect and well resistance is available in the literature.

In this paper, the authors present mathematical solutions to the above problem. The effects of the length of vertical drain, anisotropic soil permeability, and vacuum pressure are considered, and a reduction in consolidation time through vacuum preloading is compared to other available methods. Design charts eliminating cumbersome iteration procedures are then developed using the equivalent drain diameter as an independent variable to obtain the relevant drain spacing. 


\section{Basic equations and solutions}

To obtain the governing equation for the consolidation of soil with vertical drains, it is assumed that:

(a) Darcy's law is valid,

(b) the soil is fully saturated,

(c) water and soil are incompressible,

(d) strains are small,

(e) all vertical loads are initially carried by the excess pore pressure $u_{0}$,

(f) all compressive strains within the soil mass occur isotropically; shear strains are neglected as the unit cell is laterally confined and horizontal sections remain horizontal during consolidation,

(g) the coefficients of compressibility and permeability are constant.

The schematic representation of the problem under consideration where a vertical drain is surrounded by a smear zone is shown in Fig. 1. The basic partial differential equation for excess pore water pressure by vertical and radial drainage is (Barron 1948):

[1] $\quad \frac{\partial u(r, z, t)}{\partial t}=c_{h}\left(\frac{\partial^{2} u(r, z, t)}{\partial r^{2}}+\frac{1}{r} \frac{\partial u(r, z, t)}{\partial r}\right)+c_{v} \frac{\partial^{2} u(r, z, t)}{\partial z^{2}}$

where, $u(r, z, t)=$ excess pore pressure, $t=$ elapsed time, $r=$ radial distance from the center of the drain well, $z=$ vertical distance from the soil surface, $c_{h}=$ coefficient of consolidation for radial consolidation and $c_{v}=$ coefficient of consolidation for vertical consolidation. 
The boundary and initial conditions for Equation (1) are:

[2] $\quad u(r, 0, t)=-p_{0}$ for $t>0$ : constant vacuum pressure, $-p_{0}$ at the soil surface;

[3] $\left.\frac{\partial u}{\partial r}\right|_{r=r_{e}}=0$ for $t>0$ : impervious boundary at $r=r_{e}$;

[4] $\quad u\left(r_{w}, 0, t\right)=-p_{0}$ for $t>0$ : constant vacuum pressure, $-p_{0}$ along the drain boundary, However, vacuum pressure at the drain boundary may vary during the consolidation process.;

[5] $\left.\quad \frac{\partial u}{\partial z}\right|_{z=l}=0$ for $t>0$ : impervious boundary at the bottom of soil layer; and [6] $u(r, z, 0)=u_{0}$ for $t=0$ : initial excess pore pressure due to surcharge load.

In the above expressions, $r_{e}=$ radius of the soil cylinder dewatered by a drain, $p_{0}=$ applied vacuum pressure at the top soil surface and along the drain, $l=$ the soil thickness which equals the length of vertical drains, $u_{0}=$ initial excess pore pressure and $r_{w}=$ the equivalent radius of the drain, where $r_{w}=(a+b) / 4, a$ and $b$ are the width and thickness of PVD, respectively (Rixner et al. 1986).

Based on the method of separation of variables (Kreyszig 1999), it is appropriate to assume that,

[7] $\frac{u(r, z, t)-u(r, z, \infty)}{u(r, z, 0)-u(r, z, \infty)}=\left(\frac{u_{h}(r, t)-u_{h}(r, \infty)}{u_{h}(r, 0)-u_{h}(r, \infty)}\right)\left(\frac{u_{v}(z, t)-u_{v}(z, \infty)}{u_{v}(z, 0)-u_{v}(z, \infty)}\right)$

where, $u_{h}(r, t)=$ excess pore pressure for pure radial consolidation and $u_{v}(z, t)=$ excess pore pressure for pure vertical consolidation.

Equation (7) is more general than that introduced by Carrillo (1942) as Equation (7) can be used for both surcharge and vacuum preloading applied simultaneously. 
From Equation (7), the average excess pore pressure in the unit cell at a given time $t$ is defined as:

$$
\frac{\bar{u}_{t}-\bar{u}_{t=\infty}}{\bar{u}_{t=0}-\bar{u}_{t=\infty}}=\left(\frac{\bar{u}_{h, t}-\bar{u}_{h, t=\infty}}{\bar{u}_{h, t=0}-\bar{u}_{h, t=\infty}}\right)\left(\begin{array}{c}
\bar{u}_{v, t}-\bar{u}_{v, t=\infty} \\
\bar{u}_{v, t=0}-\bar{u}_{v, t=\infty}
\end{array}\right)
$$

where,

$$
\bar{u}_{t}=\frac{1}{\pi\left(r_{e}^{2}-r_{w}^{2}\right) l} \int_{r_{e}}^{r_{w}} \int_{0}^{l} u(r, z, t) d r d z
$$

[10] $\quad \bar{u}_{v, t}=\frac{1}{l} \int_{0}^{l} u_{v}(z, t) d z$ and

[11] $\bar{u}_{h, t}=\frac{1}{\pi\left(r_{e}^{2}-r_{w}^{2}\right)} \int_{0}^{l} \int_{r_{e}}^{r_{w}} u_{h}(r, t) d r d z$

Then substituting Equation (7) into Equation (1) yields:

$$
\frac{\partial u_{h}}{\partial t}=c_{r}\left(\frac{\partial^{2} u_{h}}{\partial r^{2}}+\frac{1}{r} \frac{\partial u_{h}}{\partial r}\right) \text { and }
$$

[13] $\frac{\partial u_{v}}{\partial t}=c_{v} \frac{\partial^{2} u_{v}}{\partial z^{2}}$

where, $c_{h}=k_{h} / m_{v} \gamma_{w}$ and $c_{v}=k_{v} / m_{v} \gamma_{w}$ are the radial and vertical coefficients of consolidation, respectively, $\gamma_{w}=$ is the unit weight of water, $m_{v}$ is the coefficient of soil compressibility, and $k_{h}$ and $k_{v}$ are the horizontal and vertical permeability, respectively.

The problem has now been reduced into two problems for $u_{h}$ and $u_{v}$. In summary, Equations (3)-(6), (11) and (12) define radial consolidation problem, whereas, Equations (2), (5), (6), (10) and (13) define vertical consolidation problem. 
For radial consolidation analysis, the assumptions, the boundary conditions, and the initial conditions are similar to the solution proposed earlier by Indraratna et al. (2005). Based on the governing Equation (12), the boundary conditions (Equations 35) and the initial condition (Equation 6), the average excess pore pressure ratio $\left(\frac{\bar{u}_{h, t}}{u_{0}}\right)$ in the radial direction at a given time $t$ is:

[14a] $\frac{\bar{u}_{h, t}}{u_{0}}=\left(1+\frac{p_{0}}{u_{0}}\right) \exp \left(\frac{-8 c_{h} t}{\mu d_{e}^{2}}\right)-\frac{p_{0}}{u_{0}}$

In the above equation,

$$
\begin{aligned}
\mu= & \frac{n^{2}}{n^{2}-1}\left[\ln \left(\frac{n}{s}\right)+\frac{k_{h}}{k_{s}} \ln (s)-\frac{3}{4}\right]+ \\
& \frac{s^{2}}{n^{2}-1}\left(1-\frac{s^{2}}{4 n^{2}}\right)+\frac{k_{h}}{k_{s}} \frac{1}{n^{2}-1}\left(\frac{s^{4}-1}{4 n^{2}}-s^{2}+1\right)+ \\
& \pi \frac{2 k_{h}}{3 q_{w}} l^{2}\left(1-\frac{1}{n^{2}}\right) \\
\approx & {\left[\ln \left(\frac{n}{s}\right)+\frac{k_{h}}{k_{s}} \ln (s)-\frac{3}{4}+\pi \frac{2 k_{h}}{3 q_{w}} l^{2}\right] }
\end{aligned}
$$

[14c] $n=d_{e} / d_{w}$

$[14 \mathrm{~d}] \quad s=d_{s} / d_{w}$

where, $d_{e}=$ the diameter of soil cylinder dewatered by a drain, $d_{s}=$ the diameter of the smear zone, $d_{w}=$ the equivalent diameter of the drain, $k_{s}=$ horizontal soil permeability in the smear zone and $q_{w}=$ drain discharge capacity. For the above equation, the vacuum pressure ratio (VPR) for vacuum combined surcharge preloading can be introduced by the value of $p_{0} / u_{0}$ (i.e. applied vacuum pressure/initial excess pore pressure). For fully saturated clay, the value of $u_{0}$ is equal to the preloading pressure. 
Depending on the soil stiffness, the size and shape of the mandrel, and the installation method, the extent of the smear zone $\left(d_{s}\right)$ can usually be estimated by $d_{s}=(2-3) d_{m}$, where $d_{m}$ is the equivalent diameter of mandrel (Hansbo 1981; Indraratna and Redana 1998; Bo et al. 2000). The value of $k_{h} / k_{s}$ typically falls in the range of 1-8, whereas the value of $k_{v}$ remains more or less constant in both smear and undisturbed zones (Hansbo 1981; Indraratna and Redana 1998; Saye 2003). It can be seen that in Equation (14b), there are many factors controlling well resistance such as the discharge length $(l)$, the drain discharge capacity $\left(q_{w}\right)$, and the soil permeability $\left(k_{h}\right)$. In practice, the effect of well resistance can be neglected because modern PVDs usually provide a more than adequate $q_{w}$. Holtz et al. (1988) suggested that as long as the working discharge capacity of PVD exceeds $150 \mathrm{~m}^{3} /$ year after installation, the effect on consolidation due to well resistance (e.g. folding, increased lateral pressure, siltation etc.) may be insignificant. Indraratna and Redana (2000) described that long term well resistance becomes significant for PVD with a $q_{w}$ less than 40-60 $\mathrm{m}^{3} /$ year.

For analysing consolidation by horizontal drainage, the assumptions and the initial condition are similar to Terzaghi's one-dimensional consolidation theory (1943) except for the boundary condition of vacuum pressure (Mohamedelhassan and Shang, 2002). The average excess pore pressure ratio $\left(\frac{\bar{u}_{v, t}}{u_{0}}\right)$ at a given time $t$, based on the governing Equation (13), the boundary conditions (Equations 4-5) and the initial condition (Equation 6) is:

$$
\frac{\bar{u}_{v, t}}{u_{0}}=-\frac{p_{0}}{u_{0}}+\left(1+\frac{p_{0}}{u_{0}}\right) \sum_{m=1}^{\infty} \frac{8}{(2 m+1)^{2} \pi^{2}} \exp \left(-\left(\frac{2 m+1}{2}\right)^{2} \pi^{2} \frac{c_{v} t}{l^{2}}\right)
$$


Substituting Equations (14) and (15) into Equation (8), the average excess pore pressure ratio in both vertical and horizontal directions can be expressed by:

(a) Preloading combined with vacuum application:

[16a] $\frac{\overline{u_{t}}}{u_{0}}=-\frac{p_{0}}{u_{0}}+\left(1+\frac{p_{0}}{u_{0}}\right) \sum_{m=1}^{\infty} \frac{8}{(2 m+1)^{2} \pi^{2}} \exp \left(-\left[\left(\frac{2 m+1}{2}\right)^{2} \pi^{2} \frac{1}{c_{v h} L^{2}}+\frac{8}{\mu}\right] T_{h}\right)$

(b) Vacuum application only

[16b] $\quad \bar{u}_{t}=-p_{0}+p_{0} \sum_{m=1}^{\infty} \frac{8}{(2 m+1)^{2} \pi^{2}} \exp \left(-\left[\left(\frac{2 m+1}{2}\right)^{2} \pi^{2} \frac{1}{c_{v h} L^{2}}+\frac{8}{\mu}\right] T_{h}\right)$

where, the relevant dimensionless parameters are given by:

[16c] $\quad c_{v h}=c_{h} / c_{v}=k_{h} / k_{v}$

[16d] $L=l / d_{e}$

[16e] $\quad T_{h}=c_{h} t / d_{e}^{2}$

The advantage of the proposed Equations (16a) and (16b) is that the excess pore pressure both positive (due to surcharge load) and negative(due to vacuum pressure can be obtained simulteneuosly.

The overall average degree of consolidation with time $\left(U_{t}\right)$ can now be evaluated conveniently by:

$$
U_{t}=\left(1-\frac{u_{0}-\overline{u_{t}}}{u_{0}-\overline{u_{\infty}}}\right)
$$

Substituting Equation (16) into Equation (17) gives:

$$
U_{t}=1-\sum_{m=1}^{\infty} \frac{8}{(2 m+1)^{2} \pi^{2}} \exp \left(-\left[\left(\frac{2 m+1}{2}\right)^{2} \pi^{2} \frac{1}{c_{v h} L^{2}}+\frac{8}{\mu}\right] T_{h}\right)
$$


Equation (18) shows that the total degree of consolidation at any vacuum condition $\left(p_{0}\right)$ is uniquely related to the time factor $\left(T_{h}\right)$, vertical drain system configuration and soil anisotropic permeability $\left(\mu, L\right.$ and $\left.c_{v h}\right)$.

Once $U_{t}$ is known, As suggested by Chai et al. (2005), the associated settlement at a given time $\left(\rho_{t}\right)$ is then evaluated by the following conventional equation:

[19a] $\rho_{t}=\delta U_{t} \rho_{c}$

If the vacuum pressure is larger than the stress required to maintain a $\mathrm{k}_{0}$ condition of soil, for isotropic consolidation $\alpha$ can be calculated by:

[19b] $\quad \delta=\frac{1-\mu}{1+\mu}$

where, $\mu$ is the Poisson's ratio of the soil skeleton

In the case of no lateral strain, $\delta=1$.

For a soil thickness of $l\left(=\right.$ drain length), $\rho_{c}=$ total primary consolidation settlement, is given by:

[19b] $\rho_{c}=m_{v}\left(u_{0}+p_{0}\right) l$

In the above equation, $m_{v}$ is the average value corresponding to an effective stress increase from $\sigma_{i}^{\prime}$ to $\sigma_{i}^{\prime}+u_{0}+p_{0}$, where $\sigma_{i}^{\prime}$ is the initial effective stress.

\section{Influence of $c_{v h}, L$ and vacuum pressure ratio}

In this section, the effects of $c_{v h}, L$ and vacuum pressure ratio (VPR) are discussed. Relavent parameters used in the analysis are given in Table 1. Figure 2 shows the comparison of the total degree of consolidation when $L$ varies from 1 to 10 for $c_{v h}=1$, as calculated by Equation (18). It is evident that when $L$ increases, the radial 
consolidation becomes prominent. If $L$ is more than 10 (i.e. $l \geq 10 d_{e}$ ), the vertical consolidation can be neglected. Figure 3 illustrates the comparison of the degree of consolidation when $c_{v h}$ varies from 1 to 10 for $L=1$. As $c_{v h}=c_{h} / c_{v}$ decreases, the influence of vertical consolidation becomes significant, as expected. A comparison of degree of consolidation, normalised settlement and average excess pore pressure with variation of VPR for normally consolidated clay is shown in Fig. 4 (Equations 16 to 19) for $L=5, c_{v h}=2, \sigma_{i}^{\prime}=20 \mathrm{kPa}$ and $u_{0}=50 \mathrm{kPa}$. The degree of consolidation versus time factor curve is independent of the vacuum pressure ratio ( 3 plots coincide). Normalised settlement is defined as the ratio of settlement at any given time divided by the ultimate settlement $\left(\rho_{t} / \rho_{c}(\right.$ novac $\left.)\right)$, where $\rho_{c}$ (novac) is based on the conventional method (no vacuum). As expected, the rate of settlement with a vacuum pressure is greater than conventional loading (surcharge only) without a vacuum pressure. Figure 4 also shows that, at the higher VPR, both the rate of settlement and the final settlement are increased. This is analogous to increasing the applied surcharge load without any increase in the initial excess pore pressure $\left(u_{0}\right)$. Clearly, the application of a vacuum increases the lateral pore pressure gradient, thus promoting radial flow. From the analysis, it shows that for very long vertical drains $\left(l \geq 10 d_{e}\right)$, the effect of vertical consolidation is insignificant, and the anisotropic soil permeability plays a significant role in controlling the consolidation. 


\section{Application to Case Histories}

\section{The Port of Huanghua}

The Port of Huanghua is located about $90 \mathrm{~km}$ to the east of Cangchou in Hebei Province, China (Gao, 2004). The soil consists of a very soft hydraulic fill (dredged from the harbour basin) $4 \mathrm{~m}$ in thickness, underlain by more than $16 \mathrm{~m}$ of soft, thick clayey soil. Based on an in-situ investigation in a pilot area, the consolidation characteristics of the soil can be summarised as follows: the horizontal coefficient of consolidation $\left(c_{h}\right)$ ranges from $3 \times 10^{-2}$ to $7 \times 10^{-2} \mathrm{~m}^{2} /$ day, and the undrained shear strength varies from 1.6 to $6.0 \mathrm{kPa}$. It can be noted that the values of $c_{h}$ are very high at a depth of $4.30-7.60 \mathrm{~m}$ and $9.40-12.10 \mathrm{~m}\left(c_{h} \approx 7 \times 10^{-2} \mathrm{~m}^{2} /\right.$ day $)$. In addition, preloading using surcharge fill cannot be applied in this area because the top soil layer has a very low shear strength. Therefore, vacuum preloading was considered to be the most appropriate method. PVDs $18.5 \mathrm{~m}$ long were installed in a square pattern at a spacing of $1.5 \mathrm{~m}$. Subsequently, a perforated pipe system for water collection was installed after placing a sand layer. Airtight seals were provided by a membrane liner submerged in a trench at the border of the improved area. A vacuum pressure up to 80kPa was applied for almost 3 months. The observations (i.e. degree of consolidation and pore pressure reduction) are compared with the analytical results in Fig. 5, based on Equations (16) and (18). An analysis is conducted for upper and lower bounds of $c_{h}\left(0.07\right.$ and $0.04 \mathrm{~m}^{2} /$ day $)$, and a prediction based on the average value of $c_{h}=0.05 \mathrm{~m}^{2} /$ day is also plotted. The values of $s=3$ and $k_{h} / k_{s}=2$ were applied in the analysis (Saye, 2003). It can be seen that the prediction of the total degree of consolidation using an average value of $c_{h}\left(0.05 \mathrm{~m}^{2} /\right.$ day $)$ slightly underestimates the field measurements (Fig. 5a). The observed pore pressure reductions at $0.75 \mathrm{~m}$ away 
from centreline and at $12 \mathrm{~m}$ depth also match reasonbly well for average value of $c_{h}=0.05 \mathrm{~m}^{2} /$ day (Fig. $\left.5 \mathrm{~b}\right)$.

\section{An oil storage station, Tainjin, China}

An oil storage station, constructed in 1996, is located near the coast of Tainjin, China (Chu et. al. 2000). At this site, the top 6m clay layer was reclaimed from soft clay with a very high water content taken from seabed. Underneath the soft clay layer, a marine clay deposit is found at a depth of $6-20 \mathrm{~m}$, underlain by a stiff sandy silt layer. The undrained shear strength of the soils was low $(10-30 \mathrm{kPa})$. The coefficient of horizontal consolidation $\left(c_{h}\right)$ varied in the range of $0.01-0.03 \mathrm{~m}^{2} /$ day. Vacuum preloading rather than conventional preloading by surcharge fill was considered to be a suitable method, because the shear strength of the soils was very low, especially near the ground surface. Treatment of the soft soil began by placing a $2 \mathrm{~m}$ thick, dry clayey fill and a $0.3 \mathrm{~m}$ sand blanket to serve as a firm platform. Subsequently, PVDs were installed in a square pattern at a spacing of $1 \mathrm{~m}$ to a depth of $20 \mathrm{~m}$. Horizontal drains installed in a transverse and longitudinal direction linked PVDs to the vacuum pump. PVC membranes were placed on the surface to prevent air leaks. Instruments such as pore water pressure gauges and multi-level settlement points were installed in Section I and II. A vacuum of $80 \mathrm{kPa}$ was applied for almost 90 days. Figure 6 illustrates field measurements (i.e. the degree of consolidation and pore pressure reduction) compared with the analytical results, based on Equations (16) and (18). Three different $c_{h}$ values (upper and lower bounds, and average value) were considered in the analytical model. The values of $s=3$ and $k_{h} / k_{s}=2$ were assumed in the analysis. The settlement prediction using an average value of $c_{h}$ slightly underestimates the field measurements (Fig. 6a), and the prediction of average pore 
pressure reduction compares well with the measured data points at $0.5 \mathrm{~m}$ away from the centreline (Fig. 6b). This implies that the proposed solution is acceptable for predicting vacuum assisted preloading as long as the soil properties are accurately known.

\section{Design charts}

In practice, most design charts for vertical drains employ dimensionless horizontal time factor - consolidation curves $\left(T_{h}\right.$ vs. $\left.U_{h}\right)$ to obtain the drain spacing $(S)$ as a function of $n$ (Barron 1948). Usually, a number of iterations have to be performed to obtain required parameters such as $n$ (Hartlen and Wolski 1996, Bo et al. 2003).As the availability of the size of PVDs is limited by the manufacturer, the appropriate design charts should be re-established using the equivalent drain diameter $\left(d_{w}\right)$ as a known variable in order to determine the drain spacing $\left(d_{e}\right.$ or $\left.S\right)$.

Rearranging Equation (18) gives:

[20] $\quad \gamma=-\frac{8 T_{h}^{\prime}}{\ln \left(\frac{1-U_{t}}{u^{*}}\right)}$ where,

$$
u^{*}=\sum_{m=1}^{\infty} \frac{8}{(2 m+1)^{2} \pi^{2}} \exp \left(-\left(\frac{2 m+1}{2}\right)^{2} \pi^{2} T_{v}\right)
$$

[22] $\quad T_{v}=c_{v} t / l^{2}$

[23] $\quad T_{h}^{\prime}=c_{h} t / d_{w}^{2}$, and

[24a] $\quad \gamma=n^{2}[\ln n+\xi-0.75]$, where

[24b] $\quad \xi=\left(\frac{k_{h}}{k_{s}}-1\right) \ln (s)$ 
Figure 7 shows the relationships between $T_{v}$ and $u^{*}$ as represented by Equation (21). Figure 8 illustrates the contour plot of $\xi$ (Equation 24b) when the values of $\frac{k_{h}}{k_{s}}$ and $s$ are in the range of 1-8 and 2-8, respectively. To avoid the trial and error procedure, it is necessary to determine $n$ as a function of $\gamma$ (Equation 25 and Fig. 9). Employing a linear regression analysis $\left(R^{2}>0.99\right), n$ can be arbitrarily expressed by:

[25a] $n=\exp (\alpha \ln \gamma+\beta) ; \quad$ where,

[25b] $\quad \alpha=0.3938-9.505 \times 10^{-4} \xi^{1.5}+0.03714 \xi^{0.5}$ and

$[25 \mathrm{c}] \quad \beta=0.4203+1.456 \times 10^{-3} \xi^{2}-0.5233 \xi^{0.5}$

The values of $\xi$ are in the range of 0 and 14, when the values of $\frac{k_{h}}{k_{s}}$ and $s$ fall between 2-8 and 3-8, respectively. Figure 9 shows a comparison between Equations (24) and (25) for a given $\xi$. It shows that in lieu of Equation (24), the proposed Equation (25) can be incorporated in the development of a convenient design procedure. The relationships of $\xi, \alpha$ and $\beta$ based on Equations (25b) and (25c) are plotted in Fig. 10. Once $\gamma$ is determined from Equation (20), $n$ can be calculated based on Equation (25) via Fig. 10, or alternatively using Equations (25b) and (25c). When $n$ is determined and the equivalent drain diameter, $d_{w}$ is already known, the diameter of the influence zone $d_{e}$, can be determined by $d_{e}=n d_{w}$. Subsequently, when the drain pattern is chosen, the drain spacing, $S$ can be obtained by knowing the diameter of the influence zone $d_{e}$ 


\section{Summary of the Design Steps:}

1. In-situ and soil laboratory testing to obtain the compressible soil properties. Determine the depth of installation $(l)$, and the time $(t)$ required for the consolidation process;

2. Determine the required degree of consolidation $U_{t}$ for surcharge only;

3 . In the case of a vacuum application, determine the vacuum pressure $p_{0}$, and then determine the new required degree of consolidation to obtain the same amount of settlement from $U_{t, v a c} / U_{t}=\rho_{c}($ novac $) / \rho_{c}($ vac $)$;

4. Based on the value of $c_{v}, t$ and $l$, determine $u^{*}$ using Equation (21) or Fig. 7

5. Choose the size of the prefabricated vertical drains and then calculate the equivalent drain diameter, $d_{w}$ from $d_{w}=2(a+b) / \pi$;

6. Determine $T_{h}^{\prime}$ from Equation (23);

7. Determine $\gamma=-\frac{8 T_{h}^{\prime}}{\ln \left(\frac{1-U_{t}}{u^{*}}\right)}$ for surcharge only or $\gamma=-\frac{8 T_{h}^{\prime}}{\ln \left(\frac{1-U_{t, v a c}}{u^{*}}\right)}$ for vacuum plus surcharge;

8. Determine the diameter and permeability of the smear zone based on the vertical drain installation procedure, the size of mandrel and the type of soil;

9. Calculate $\xi$ by Equation (24b) or Fig. 89;

10. Determine $n$ from $\xi$ using Equation (25) and Fig. 10;

11. Determine the zone of influence $\left(d_{e}=n d_{w}\right)$, and;

12. Select the drain pattern and calculate the drain spacing $(d)$ from either $d$ $=d_{e} / 1.05$ or $d=d_{e} / 1.128$ for triangular or square grid pattern, respectively; 


\section{Example}

The methodology is illustrated by the following example. The required soil parameters for normally consolidated clay are assumed to be:

$U_{t}=90 \%, l=10 m, d_{w}=0.06 \mathrm{~m}, c_{h}=2.0 \mathrm{~m}^{2} /$ year, $c_{v}=1.0 \mathrm{~m}^{2} /$ year, $k_{h} / k_{s}=5, s=3$, $t=1$ year, $u_{0}=40 \mathrm{kPa}, \delta=1$ and $\sigma_{i}^{\prime}=50 \mathrm{kPa}$. Well resistance is ignored. Determine the drain spacing $(d)$, for (a) surcharge load only, and (b) surcharge loading plus a vacuum of $60 \mathrm{kPa}$

\section{Solution:}

\section{(a) Surcharge load only}

1. $T_{v}=1 \times 1 / 10^{2}=0.01$

2. Determine $u^{*}$ using Equation (21) or Fig. 7, Hence, $u^{*}=0.89$

$3 . T_{h}^{\prime}=c_{h} t / d_{w}^{2}=2.0 \times 1 / 0.06^{2}=555.56$

4. $\gamma=-\frac{8 T_{h}^{\prime}}{\ln \left(\frac{1-U_{t}}{u^{*}}\right)}=-\frac{8 \times 555.56}{\ln \left(\frac{1-0.9}{0.89}\right)}=2036.07$

5. Use Fig. 8 or Eqaution (24b), $\xi=4.39$

6. Use Fig. 10 or Equations (25b) and (25c) to find $\alpha$ and $\beta$. Hence, $\alpha=0.463$ and $\beta=-0.649$.

7. From Equation $(25 \mathrm{a}), n=\exp (\alpha \ln \gamma+\beta)=\exp (0.463 \times \ln 2036.07-0.649)=18$

8. Determine $d_{e}$ from $d_{e}=18 \times 0.06=1.08 \mathrm{~m}$

9. Therefore drain spacing $=1.03 \mathrm{~m}$ or $0.96 \mathrm{~m}$ for square or triangular patterns, respectively.

\section{(b) surcharge with a vacuum $60 \mathrm{kPa}$}

1. $T_{v}=1 \times 1 / 10^{2}=0.01$ 
2. Determine $u^{*}$ using Equation (21) or Fig. 7, Hence, $u^{*}=0.89$

3. $T_{h}^{\prime}=c_{h} t / d_{w}^{2}=2.0 \times 1 / 0.06^{2}=555.56$ and the new required degree of consolidation is $U_{t, v a c}=\frac{0.9 * 40}{40+60}=0.36$

4. $\gamma=-\frac{8 T_{h}^{\prime}}{\ln \left(\frac{1-U_{t, v a c}}{u^{*}}\right)}=-\frac{8 \times 555.56}{\ln \left(\frac{1-0.36}{0.89}\right)}=13478.20$

5. Use Fig. 8 or Eqaution (24b), $\xi=3.64$

6. Use Fig. 10 or Equations (25b) and (25c) to find $\alpha$ and $\beta$. Hence, $\alpha=0.463$ and $\beta=-0.649$.

7. $n=\exp (\alpha \ln \gamma+\beta)=\exp (0.463 \times \ln 13478.20-0.649)=43$

8. Determine $d_{e}$ from $d_{e}=43 \times 0.06=2.58 \mathrm{~m}$

9. Therefore the drain spacing $=2.45 \mathrm{~m}$ or $2.29 \mathrm{~m}$ for square or triangular patterns, respectively.

\section{Conclusions}

A system of vertical drains combined with vacuum preloading is an effective method for accelerating soil consolidation. In this study, an analytical model for consolidation for both vertical and radial drainage incorporating vacuum preloading as well as smear and well resistance was developed. The consolidation of soil with vertical and horizontal drainage is governed by the dimensionless parameters $L, c_{v h}$ and VPR. It was found that $L\left(=l / d_{e}\right)$, which is the ratio between the length of vertical drains $l$ and diameter of influence zone $d_{e}$, is an important parameter influencing the effectiveness of vertical consolidation. When $L$ is equal to 10 or more, vertical consolidation can be neglected. When $c_{v h}$ is 10 or greater, the effect of vertical 
consolidation may be insignificant. It is noted from the findings of this study that if the vacuum pressure ratio (VPR) is less than 0.25 , the effect of vacuum preloading is insignificant. The predictions of the proposed analytical solutions for vacuum assisted consolidation were compared, and they agreed with the actual field data.

Suitable design charts for vertical drains were developed considering both vertical and horizontal drainage. As a result, the conventional and often cumbersome trial and error methods to estimate the appropiate parameters could be avoided. Once the equivalent drain diameter $d_{w}$ and other relevant parameters are known, the influence zone diameter $d_{e}$ can be readily obtained without any further iterations or interpolations. By employing these design charts, even manual calculation can be done rapidly without the aid of a computer. These preliminary design charts were extended to represent a larger array of soil properties and drain patterns, on the basis of the same governing equations presented here. 


$$
\begin{aligned}
& \text { Notations } \\
& \text { a } \\
& =\text { width of vertical drain }(\mathrm{m}) \\
& b \quad=\text { thickness of vertical drain (m) } \\
& c_{h} \quad=\text { coefficient of consolidation for radial (horizontal) drainage }\left(\mathrm{m}^{2} / \mathrm{s}\right) \\
& \left(c_{h}=k_{h} / m_{v} \gamma_{w}\right) \\
& c_{v} \quad=\text { coefficient of consolidation for vertical drainage }\left(\mathrm{m}^{2} / \mathrm{s}\right) \\
& \left(c_{v}=k_{v} / m_{v} \gamma_{w}\right) \\
& c_{v h} \quad=c_{h} / c_{v}=k_{h} / k_{v} \\
& d_{e} \quad=\text { diameter of influence zone }(\mathrm{m}) \\
& d_{m} \quad=\text { equivalent diameter of mandrel (m) } \\
& d_{s} \quad=\text { diameter of smear zone }(\mathrm{m}) \\
& d_{w} \quad=\text { equivalent diameter of vertical drain }(\mathrm{m}) \\
& e_{0} \quad=\text { average void ratio at initial in-situ effective stress } \\
& k_{h}=\text { coefficient of horizontal permeability in the undisturbed zone }(\mathrm{m} / \mathrm{s}) \\
& k_{v} \quad=\text { coefficient of vertical permeability }(\mathrm{m} / \mathrm{s}) \\
& k_{s} \quad=\text { coefficient of horizontal permeability in the smear zone }(\mathrm{m} / \mathrm{s}) \\
& l=\text { vertical drain length }=\text { soil thickness }(\mathrm{m}) \\
& L \quad=l / d_{e} \\
& m \quad=\text { integer } \\
& m_{v} \quad=\text { coefficient of soil compressibility }\left(\mathrm{m}^{2} / \mathrm{kN}\right) \\
& n \quad=\text { dimensionless parameter } n=d_{e} / d_{w} \\
& p_{c}^{\prime} \quad=\text { preconsolidation pressure }(\mathrm{kPa}) \\
& p_{0} \quad=\text { applied vacuum pressure }(\mathrm{kPa})
\end{aligned}
$$




$$
\begin{aligned}
& q_{w} \quad=\text { drain discharge capacity }\left(\mathrm{m}^{3} / \mathrm{s}\right) \\
& r \quad=\text { radius; coordinate in the cylindrical coordinate system }(\mathrm{m}) \\
& r_{e} \quad=\text { radius of influence zone }(\mathrm{m}) \\
& r_{s} \quad=\text { radius of smear zone }(\mathrm{m}) \\
& r_{w} \quad=\text { equivalent radius of vertical drain (m) } \\
& s \quad=\text { dimensionless smear ratio } s=d_{s} / d_{w} \\
& S \quad=\text { drain spacing }(\mathrm{m}) \\
& t \quad=\text { elapsed time }(\mathrm{s}) \\
& t_{\text {req }} \quad=\text { required time of consolidation } \\
& T_{h} \quad=\text { dimensionless time factor }\left(T_{h}=c_{h} t / d_{e}^{2}\right) \\
& T_{h}^{\prime} \quad=\text { modified horizontal time factor in terms of } d_{w} T_{h}^{\prime}=c_{h} t / d_{w}^{2} \\
& T_{v} \quad=\text { dimensionless vertical time factor }\left(T_{v}=c_{v} t / l^{2}\right) \\
& u(r, z, t) \quad=\text { excess pore pressure }(\mathrm{kPa}) \\
& \bar{u}_{h, t} \quad=\text { average horizontal excess pore pressure }(\mathrm{kPa}) \\
& u_{h}(r, t) \quad=\text { excess pore pressure for pure radial consolidation }(\mathrm{kPa}) \\
& \bar{u}_{v, t} \quad=\text { average vertical excess pore pressure }(\mathrm{kPa}) \\
& u_{v}(z, t) \quad=\text { excess pore pressure for pure vertical consolidation }(\mathrm{kPa}) \\
& \bar{u}_{t} \quad=\text { overall average excess pore pressure }(\mathrm{kPa}) \\
& u(r, z, t) \quad=\text { overall excess pore pressure }(\mathrm{kPa}) \\
& u_{0} \quad=\text { initial excess pore pressure }(\mathrm{kPa}) \\
& U_{h} \quad=\text { average degree of horizontal consolidation } \\
& U_{t} \quad=\text { overall average degree of consolidation }
\end{aligned}
$$


VPR

$=$ vacuum pressure ratio $\left(p_{0} / u_{0}\right)$

$z \quad=$ depth $(\mathrm{m})$

\section{Greek letters}

$\delta \quad=$ a modified factor for settlement

$\gamma_{w} \quad=$ unit weight of water $\left(\mathrm{kN} / \mathrm{m}^{3}\right)$

$\gamma, \xi, \alpha, \beta=$ modified smear and well resistance factor

$\rho_{t} \quad=$ settlement at a given time $(\mathrm{m})$

$\rho_{c} \quad=$ total primary consolidation settlement $(\mathrm{m})$

$\mu \quad=$ smear and well resistance factor

$\sigma_{i}^{\prime} \quad=$ in-situ vertical effective stress or initial vertical effective stress $(\mathrm{kPa})$ 


\section{References:}

Barron, R. A. 1948. The influence of drain wells on the consolidation of fine-grained soils. Diss., Providence, U S Eng. Office.

Bo, M.W., Bawajee, R., Chu, J., and Choa, V. 2000. Investigation of smear zone around vertical drain. In Proceedings of the Third International Conference on Ground Improvement Techniques, Sigapore. pp. 109-114.

Bo, M.W., Chu, J., Low, B.K. and Choa, V. 2003. Soil improvement; prefabricated vertical drain techniques. Thomson Learning, Singapore, $341 \mathrm{p}$.

Carrillo, N. 1942. Simple two - and three-dimensional cases in the theory of consolidationof soils. Journal of Mathematical Physics, 21: 1-5.

Chai, J.C., Carter, J.P., and Hayashi, S. 2005 Ground deformation induced by vacuum consolidation. Journal of Geotechnical and Geoenvironmental Engineering, 131(12):1552-1561.

Choa, V. 1989. Drains and vacuum preloading pilot test. In Proceedings of the 12 th ICSMFE, Rio de Janeiro. pp. 1347-1350.

Chu, J., Yan, S.W. and Yang, H. 2000. Soil improvement by the vacuum preloading method for an oil storage station. Geotechnique, 50(6): 625-632.

Cognon, J. M., Juran, I., and Thevanayagam, S. 1994. Vacuum consolidation technology- principles and field experience. In Proceedings of conference on vertical and horizontal deformations of foundations and embankments deformations, College station, Texas. pp. 1237-1248.

Gao, C. 2004. Vacuum preloading method for improving soft soils of higher permeability. Ground Improvement, 8(3): 101-107. 
Hansbo, S. 1981. Consolidation of fine-grained soils by prefabricated drains. In Proceedings of $10^{\text {th }}$ International Conference on Soil Mechanics and Foundation Engineering, Stockholm, Balkema, Rotterdam. 3. pp. 677-682.

Hartlen, J. and Wolski, W. 1996. Embankments on Organic Soils. Elsevier, 424 p.

Holtan, G.W. 1965. Vacuum stabilization of subsoil beneath runway extension at Philadelphai International Airport. In Proc. of $6^{\text {th }}$ ICSMFE, 2.

Holtz, R.D., Jamiolkowski, M.B., Lancellotta, R., and Pedroni, R. 1988. Behavior of bent prefabricated vertical drains. In the Proceedings of $12^{\text {th }}$ International Conference on Soil Mechanics and Foundation Engineering. Rio de Janeiro. 3. pp. 1657-1660.

Indraratna B., and Redana I.W. 1998. Laboratory determination of smear zone due to vertical drain installation. Journal of Geotechnical and Geoenvironmental Engineering, ASCE, 124(2): 180-184.

Indraratna B., and Redana I.W. 2000. Numerical modeling of vertical drains with smear and well resistance installed in soft clay. Canadian Geotechnical Journal. 37: 133-145.

Indraratna, B., Bamunawita, C., and Khabbaz, H. 2004. Numerical modeling of vacuum preloading and field applications. Canadian Geotechnical Journal. 41(6): 1098-1110.

Indraratna, B., Sathananthan I., Rujikiatkamjorn, C., and Balasubramaniam, A. S. 2005. Analytical and numerical modeling of soft soil stabilised by PVD incorporating vacuum preloading. International Journal of Geomechanics. 5(2): 114-124. 
Kjellman, W. 1952. Consolidation of clayey soils by atmospheric pressure. In Proceedings of a conference on soil stabilisation, Massachusetts Institute of Technology, Boston. pp. 258-263.

Kreyszig, E. 1999. Advanced engineering mathematics. $8^{\text {th }}$ Edition, John Wiley and Sons, New York.

Mohamedelhassan, E., and Shang, J.Q. 2002. Vacuum and surcharge combined onedimensional consolidation of clay soils. Canadian Geotechnical Journal. 39: $1126-1138$.

Onoue, A. 1988. Consolidation by vertical drains taking well resistance and smear into consideration. J. Soils and Foundations, 28(4): 165-174.

Qian, J.H., Zhao, W.B., Cheung, Y.K. and Lee, P.K.K. 1992. The theory and practice of vacuum preloading. Computers and Geotechnics, 13: 103-118.

Rixner, J.J., Kraener, S.R., and Smith, A.D. 1986. Prefabricated vertical drains. Report FHWA-RD-86-169. Federal Highway Administration, U.S. Department of Commerce, Washington DC. 433 p.

Saye, S.R. 2003. Assessment of soil disturbance by the installation of displacement sand drains and prefabricated vertical drains. Geotechnical Special Publication No. 119. ASCE. 325-362.

Shinsha, H., Watari, Y., and Kurumada, Y. 1991. Improvement of very soft ground by vacuum consolidation using horizontal drains. In Proceedings of the International Conference on Geotechnical Engineering for Coastal Development (Geo-Coast 91), Port and Harbor Research Institute, Yokohama, Japan. 1. pp. 387-392. 
Song, Y.S., and Kim, T.H. 2004. Improvement of estuarine marine clays for coastal reclamation using vacuum-applied consolidation method. Ocean Engineering, 31: 1999-2010.

Terzaghi, K. 1943. Theoretical Soil Mechanics, John Wiley and Sons, New York.

Yan, S.W. and Chu, J. 2003. Soil improvement for a road using a vacuum preloading method. Ground Improvement, 7(4): 165-172.

Yoshikuni, H., and Nakanodo, H. 1974. Consolidation of Fine-Grained Soils by Drain Wells with Finite Permeability. Japan Soc. Soil Mech. and Found. Eng. 14(2): $35-46$. 


\section{List of Figures}

Fig. 1. Vertical drain system (a) Triangular grid pattern, (b) Square grid pattern, (c) Typical cylindrical cell representing a vertical drain surrounded by a smear zone.

Fig. 2 Effect of $L$ on the degree of consolidation

Fig. 3 Effect of $c_{v h}$ on the degree of consolidation

Fig. 4. Effect of VPR (a) total degree of consolidation; (b) normalized settlement; and (c) average excess pore pressure ratio

Fig. 5. Comparison between measured and predicted results (a) Total average degree of consolidation and (b) pore water pressure reduction (Huanghua Port project, China, Gao, 2004)

Fig. 6. Comparison between measured and predicted results (a) Total average degree of consolidation and (b) pore water pressure reduction (Oil storage station project, China, Chu et. al, 2000)

Fig. 7. Relationship between $T_{v}$ and $u^{*}$

Fig. 8. Contour plot of $\xi$ based on Equation (24b)

Fig. 9. Comparison between approximation solution and exact solution

Fig. 10. Relationships of $\xi, \alpha$ and $\beta$ 
Table 1. Parameters used to compare the effects of $c_{v h}$, L and VPR

\begin{tabular}{cc}
\hline Parameters & Value \\
\hline$n=d_{e} / d_{w}$ & 10 \\
$s=d_{s} / d_{w}$ & 3 \\
Radial coefficient of consolidation, $c_{h}\left(\mathrm{~m}^{2} / \mathrm{yr}\right)$ & 3.0 \\
$d_{e}(\mathrm{~m})$ & 1.5 \\
$k_{h} / k_{s}$ & 3.0 \\
\hline
\end{tabular}




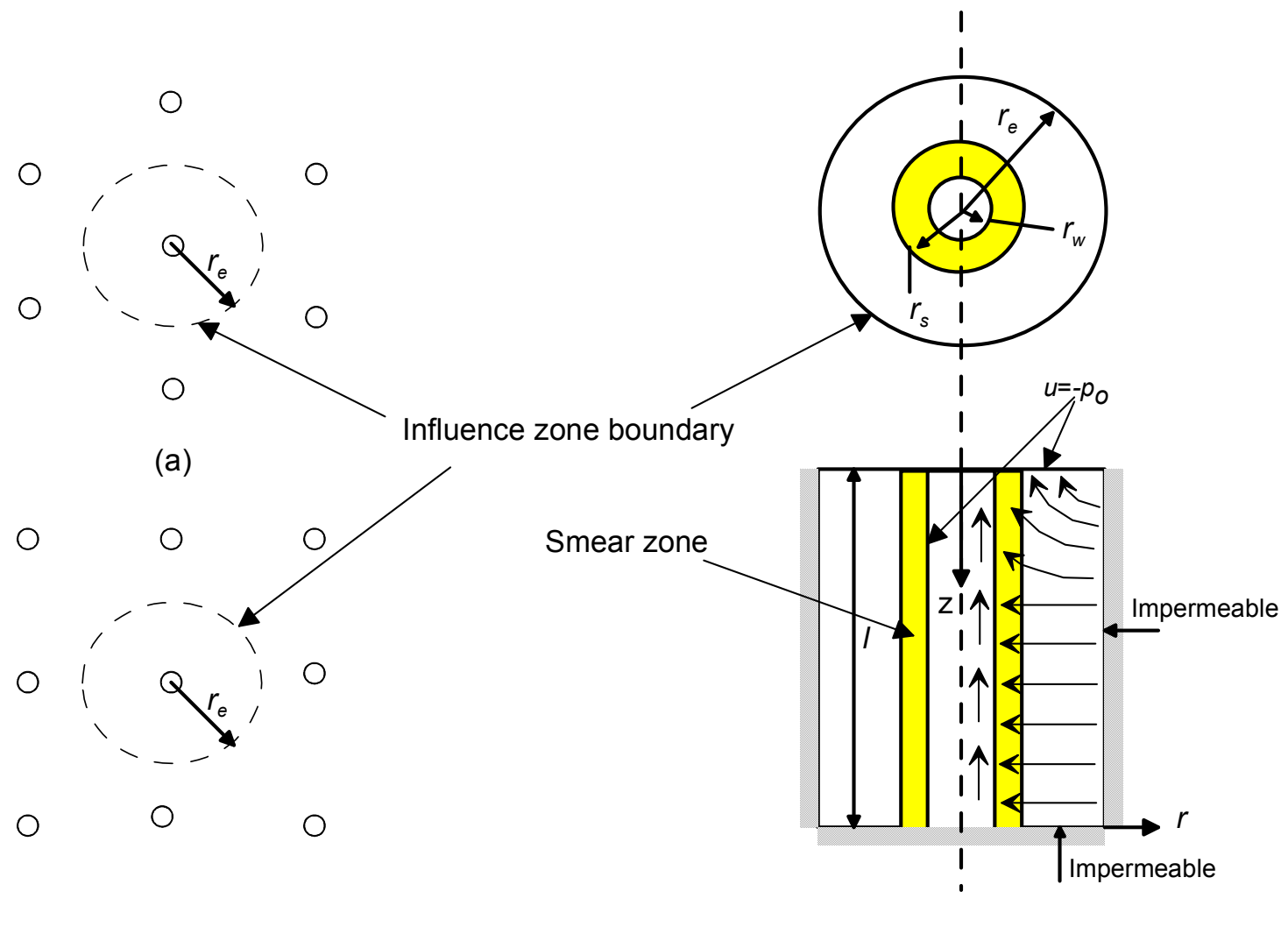

(b)

(c)

Fig. 1. Vertical drain system (a) Triangular grid pattern, (b) Square grid pattern, (c) Typical cylindrical cell representing a vertical drain surrounded by a smear zone. 


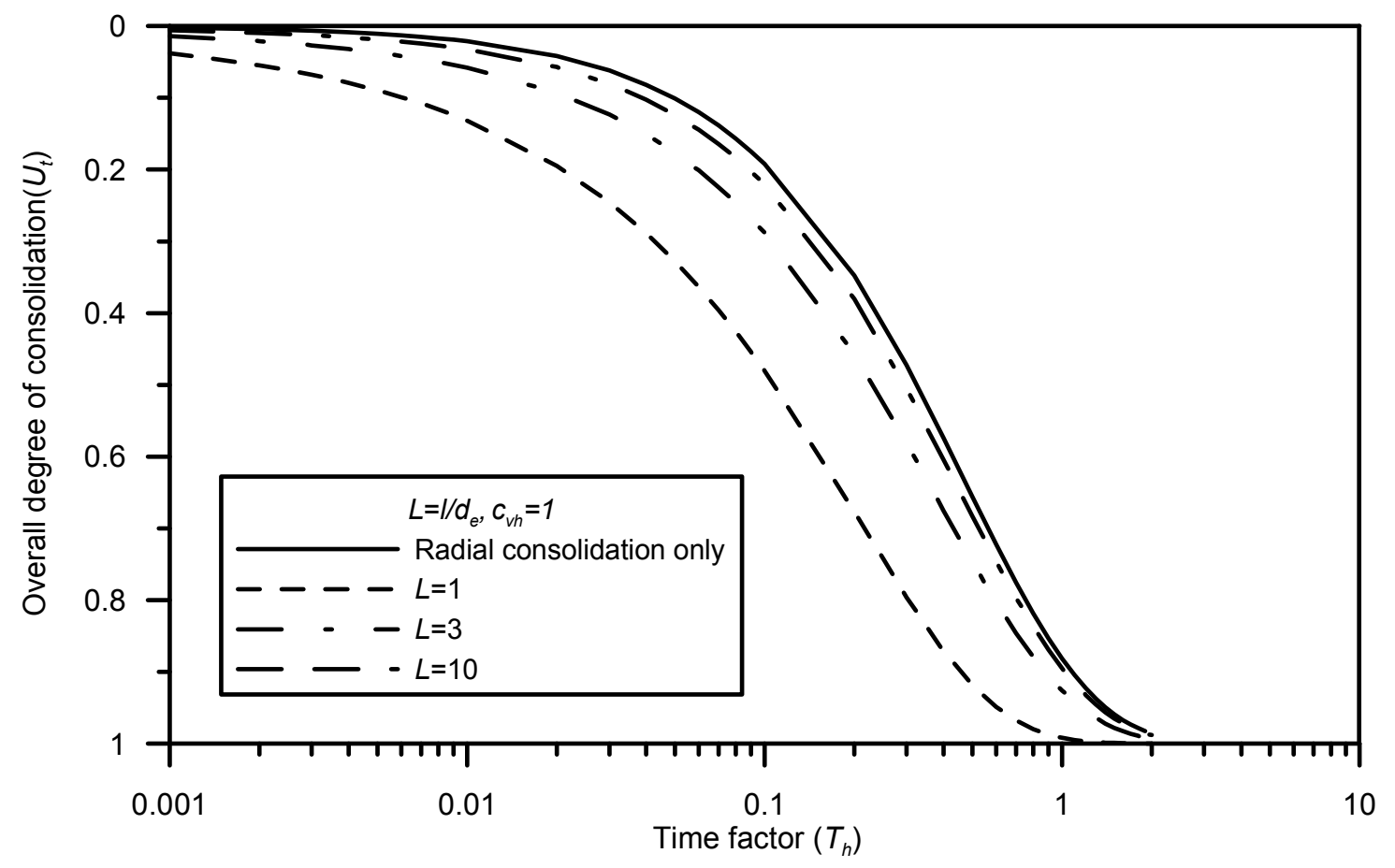

Fig. 2 Effect of $L$ on the degree of consolidation 


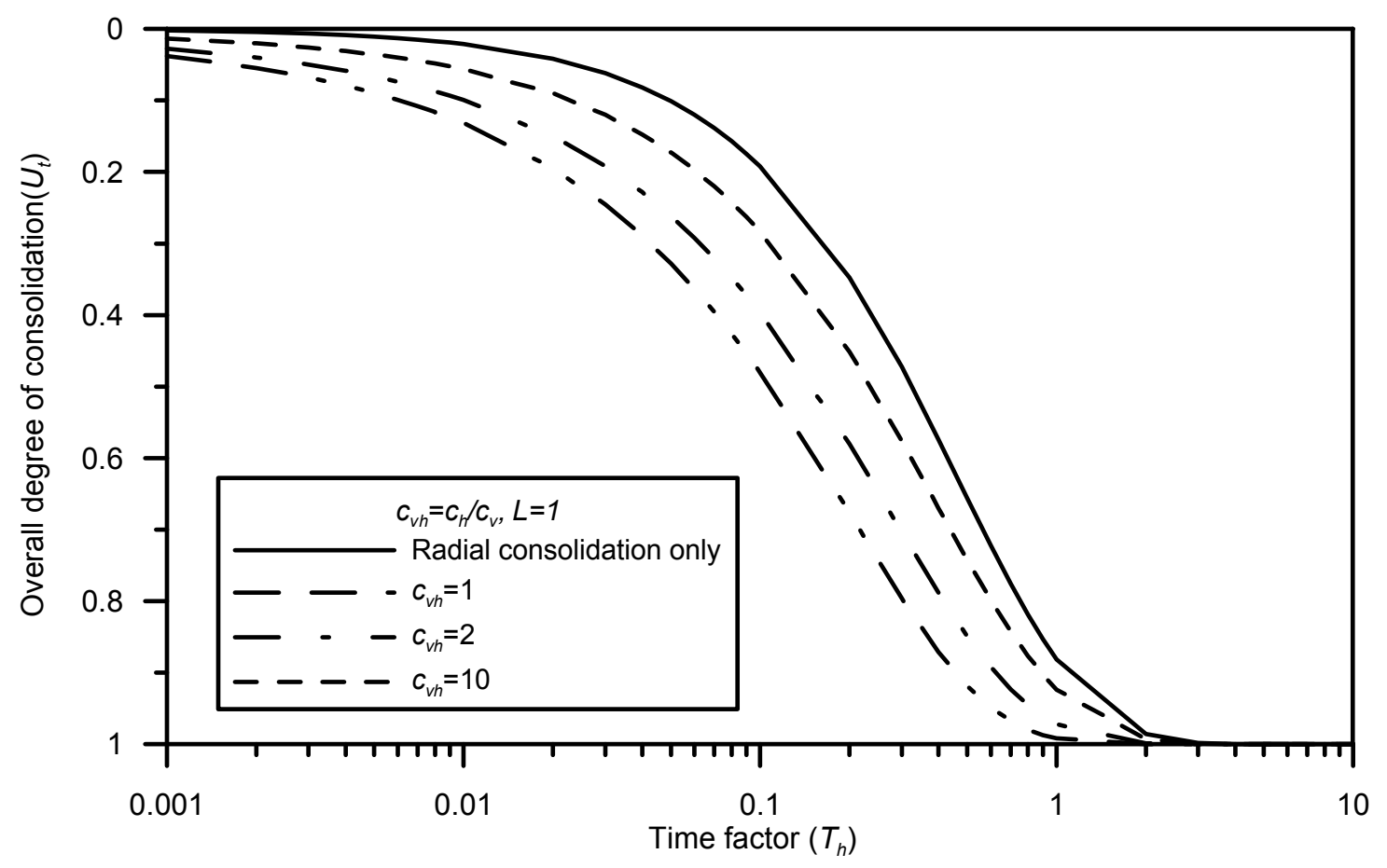

Fig. 3 Effect of $c_{v h}$ on the degree of consolidation 


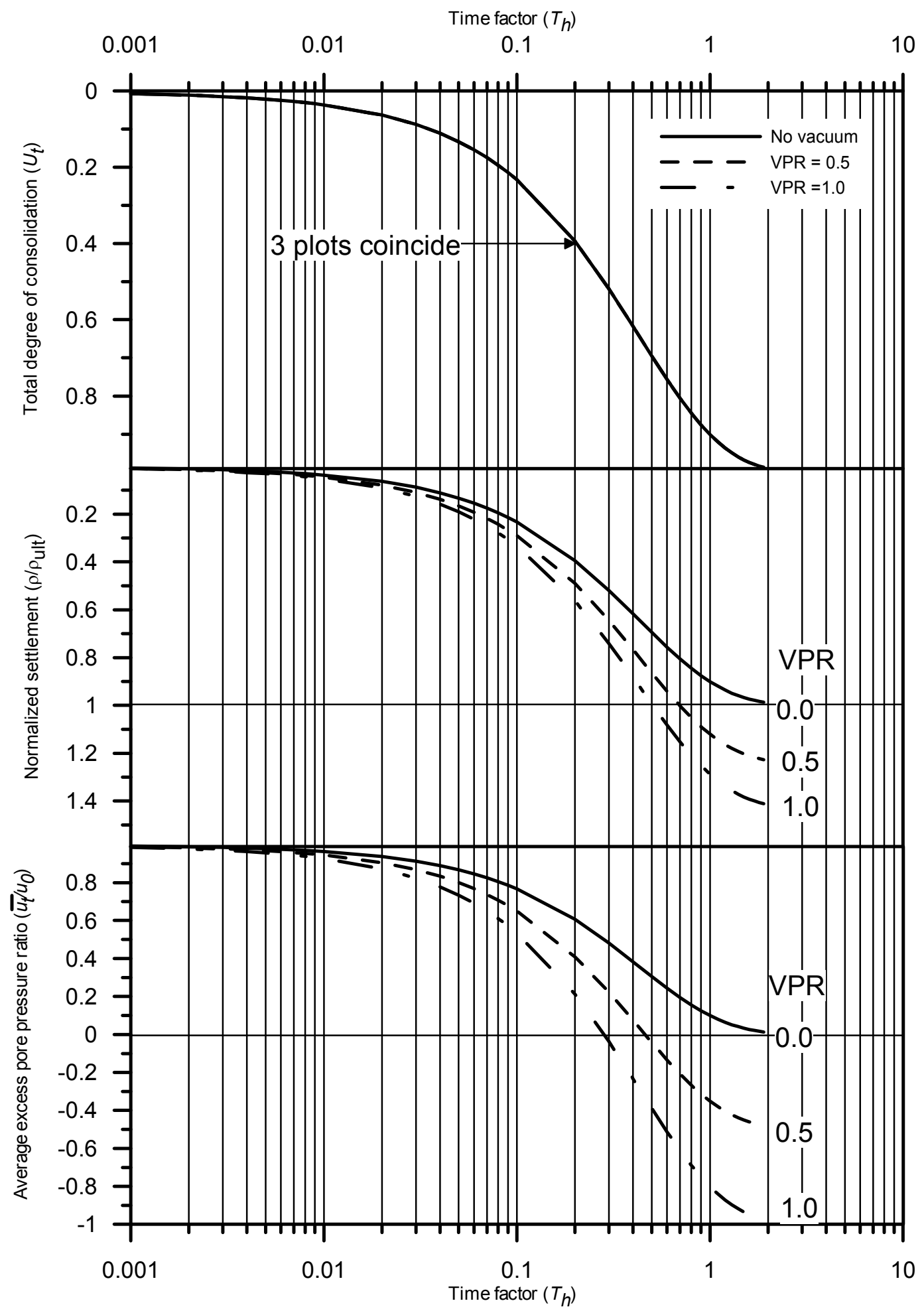

Fig. 4. Effect of VPR (a) total degree of consolidation; (b) normalized settlement; and

(c) average excess pore pressure ratio 


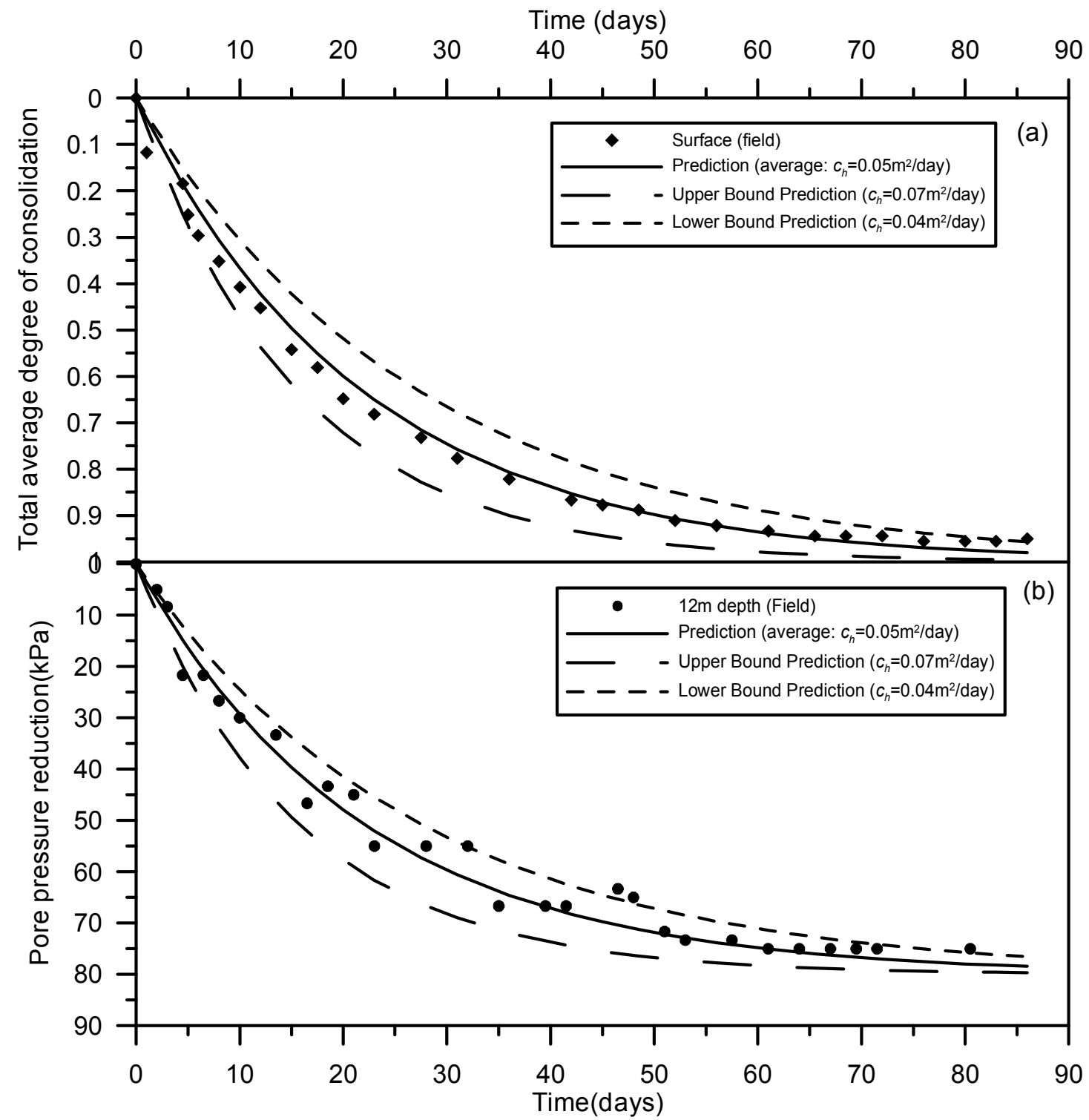

Fig. 5. Comparison between measured and predicted results (a) Total average degree of consolidation and (b) pore water pressure reduction (Huanghua Port project, China, Gao, 2004) 


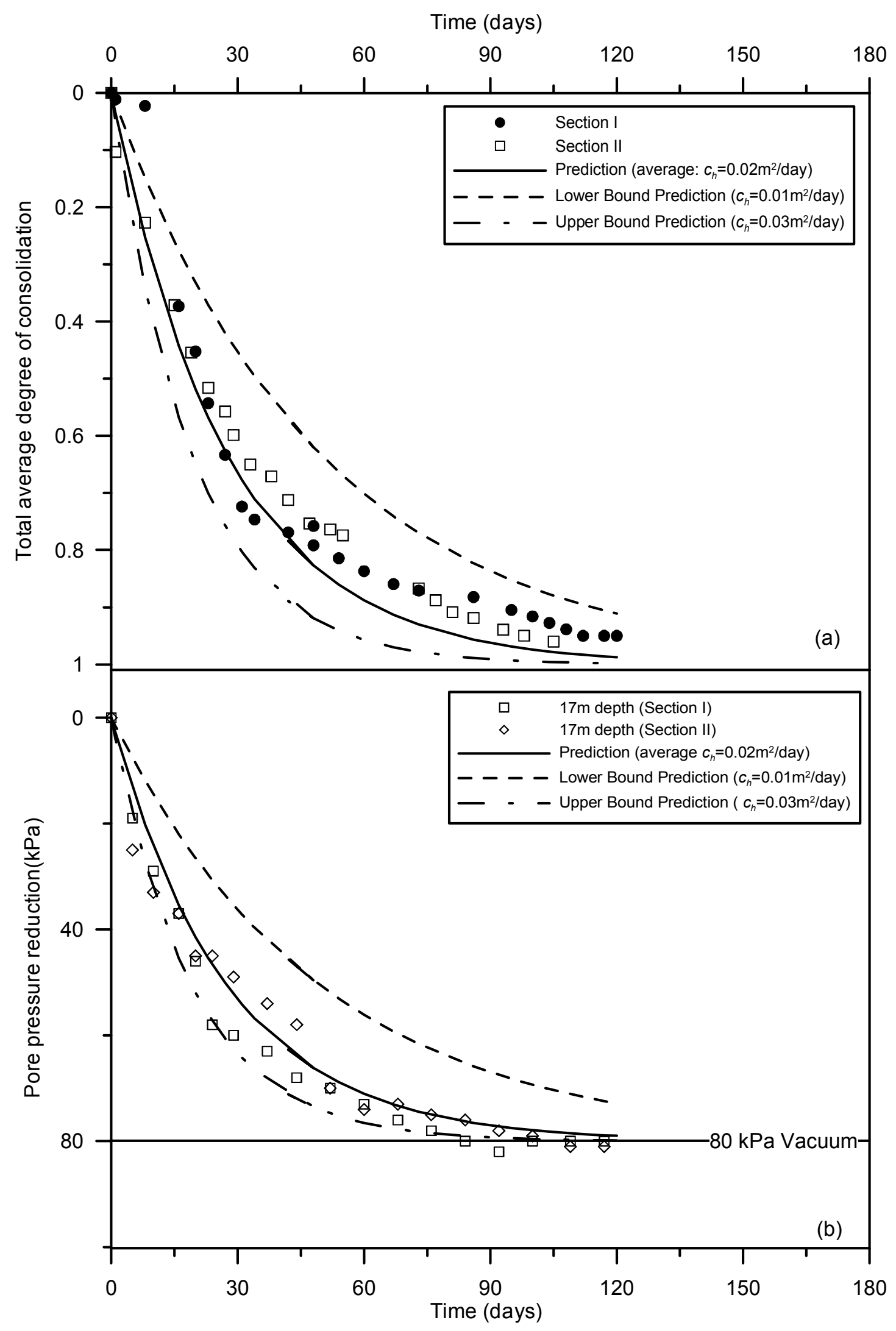

Fig. 6. Comparison between measured and predicted results (a) Total average degree of consolidation and (b) pore water pressure reduction (Oil storage station project, China, Chu et. al, 2000) 


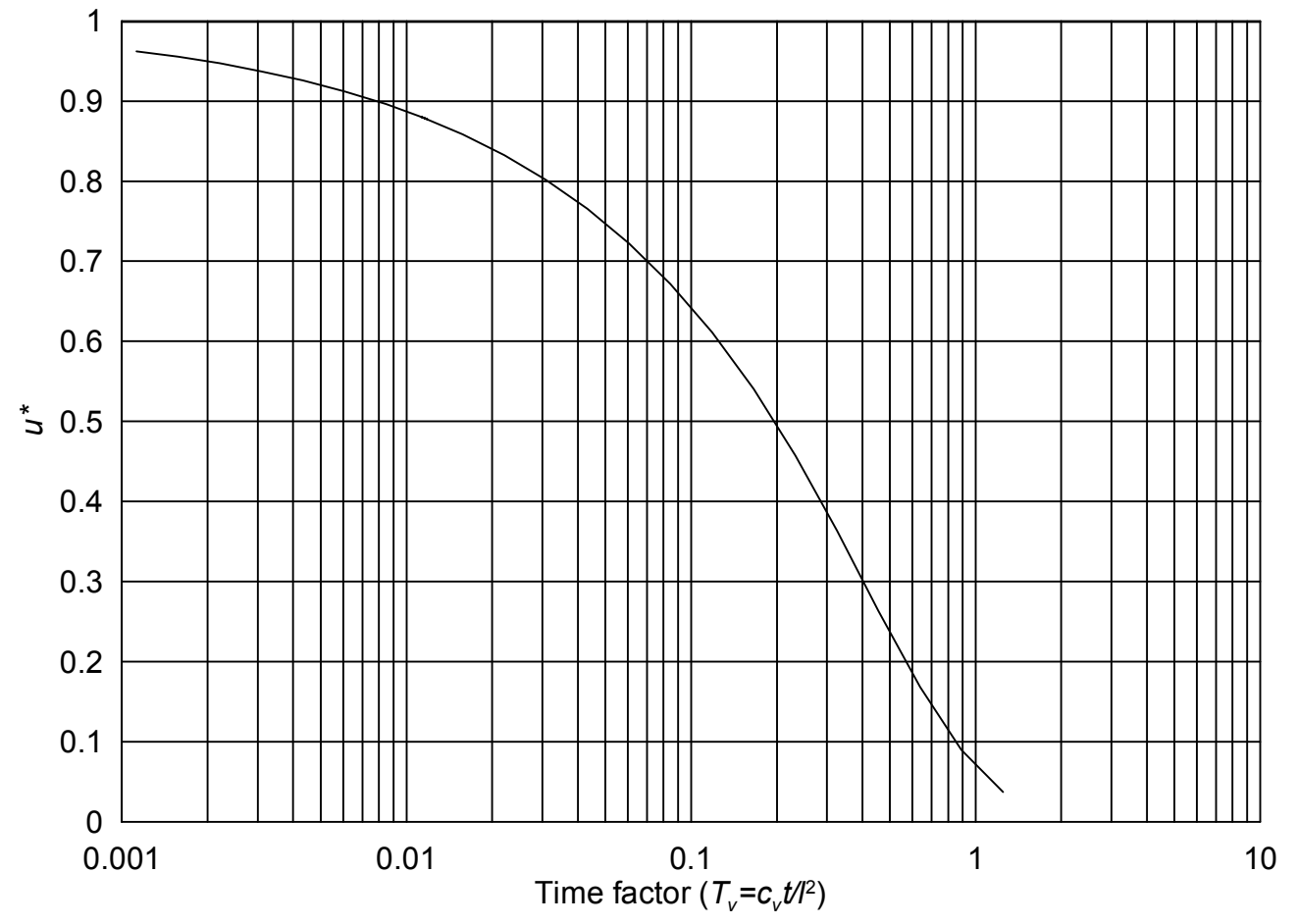

Fig. 7. Relationship between $T_{v}$ and $u^{*}$ 


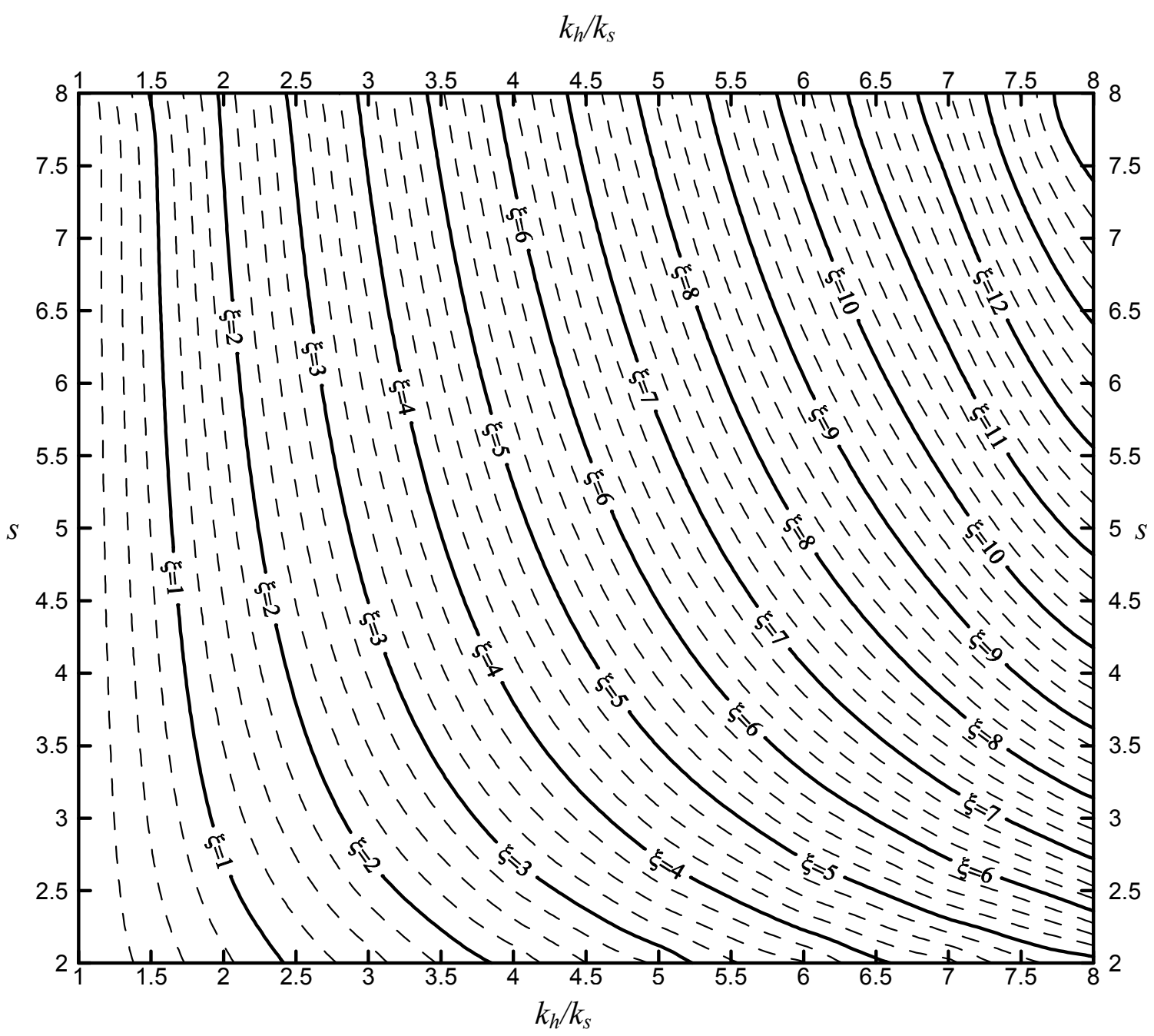

Fig. 8. Contour plot of $\xi$ based on Equation (24b) 


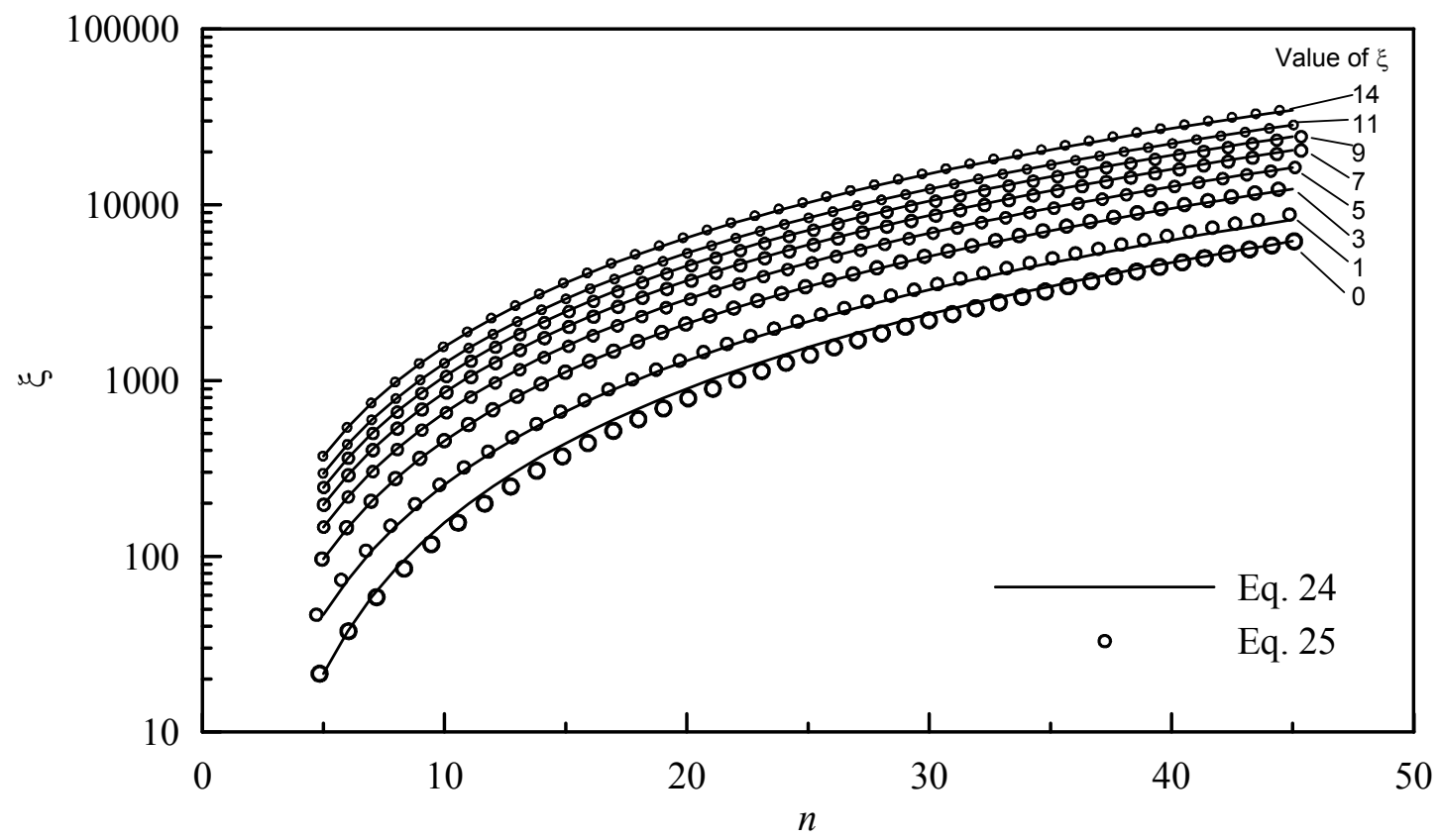

Fig. 9. Comparison between approximation solution and exact solution 


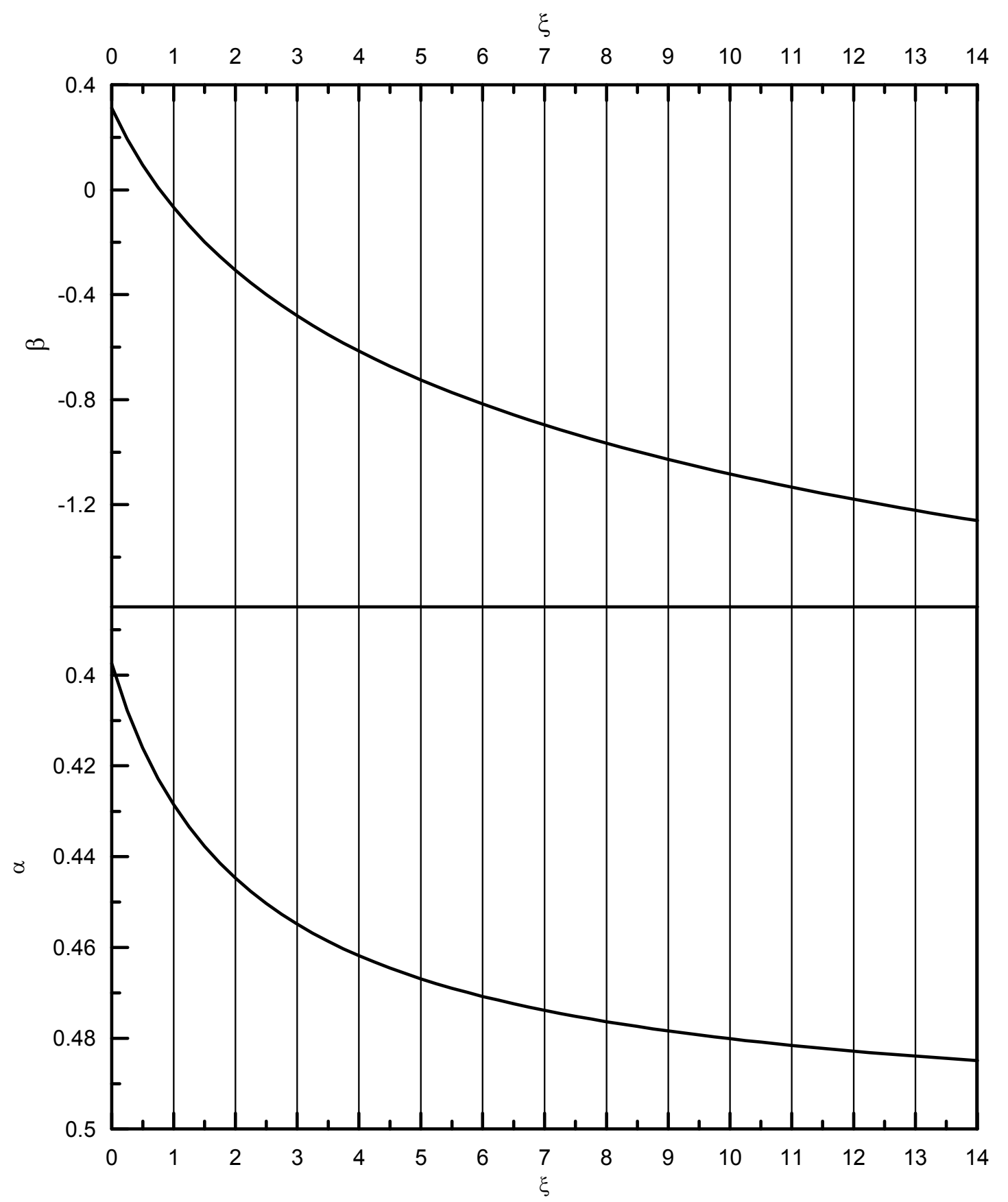

Fig. 10. Relationships of $\xi, \alpha$ and $\beta$ 